\title{
Cytotoxic and Immunetoxic Associated with Occupational Chemical Exposure, Baghdad, Iraq Azhar M Haleem $(\mathrm{PhD})^{1}$ and Afaf A Al-Sabagh $(\mathrm{MSc})^{2}$
}

\section{Abstract}

Background: Human genome widely affected by different types of chemical, physical and biological causes lead to evaluate many changes in their stability and activity.

Objective: To evaluate genotoxic and immunotoxic in mixed chemicals and/or pesticides exposed workers.

Patients and Methods: Peripheral blood lymphocytes from Iraqis men $(n=45)$ exposed to mixed chemicals and/or pesticides and from matched controls $(n=15)$ were assessed.

Results: Percentage of lymphocytes subset (CD3+, CD4+, CD8+ and natural killer (NK) cells CD16+ CD56+), as well as cytotoxicity was evaluated by means of micronucleus (MN) test and Total Chromosomal Aberrations (TCA) Micronuclei $(\mathrm{MN})$ significant $(\mathrm{P} \leq 0.05)$ difference between both groups was found $(7.11 \mathrm{MN} / 250$ cells), compared to the control group (3.1 $\mathrm{MN} / 250$ cells) and this increase occur in parallel to the frequency of Total Chromosomal Aberration (TCA), 0.44 and 0.23 per chromosome, respectively, was noted in the peripheral lymphocytes of the exposed and their matched reference group. Significant decreases in CD4+ and CD3+associated with elevation in CD8+ and NK.

Conclusion: The positive results by increasing chromosomal abnormalities represented by $\mathrm{MN}$ and SCE beside of variations in lymphocytes population in exposed people pointing to the potential genetic hazards of chemicals and pesticides on exposed people.

Keywords: Cytotoxic, Immunotoxic, Total chromosomal aberration, Micronuclei, Chemical hazards.

Corresponding Author: amhjanabi74@gmail.com

Received: $27^{\text {th }}$ August 2019

Accepted: $24^{\text {th }}$ September 2019

DOI:https://doi.org/10.26505/DJM.17024890827

${ }^{1,2}$ Environmental Research Center/ University of Technology, Baghdad, Iraq.

\section{Introduction}

Chemicals widely used in pharmaceutical, cosmetics, batteries, paints, pigments and educational materials around the world today [1 and 2] , many of these substances designed to be highly toxic like pesticides [3 and 4] people exposed to such chemicals as a result of their work in transport, storage and dealing with it. Scheduled hazardous chemicals causes serious health problems like DNA damages, cancers, infertility, kidney or liver failure and immune system disorders [5]. Continues exposure to some chemicals like heavy metals and radioactive materials may cause thier accumulate them in different 
tissues leading to death. In Iraq the workers in government approved laboratories, capitulate to occupational safety laws and the principles of occupational exposure and receive training in chemical risk management in national and international institutes, they also receive health care and periodic inspection.

Contrariwise the workers in private chemical and pesticide shops and outlets have thousands of raw chemical materials with absence of ideal storage conditions like optimum storage temperature for each type, good ventilation, safety and security equipment, personal protection equipment this lead to inevitable exposure to hazards, many chemicals have significant effects on genomic status and immunological system [6 - 9] Thus, the cytotoxic and immunotoxic were studied of occupational mixture chemicals exposure in a population of 45 workers from three Iraqi chemical sale markets and 15 controls. The exposure was evaluated by analyzing percentage of lymphocytes subset (CD3+, CD4+, CD8+ and natural killer (NK) cells), cytotoxicity was evaluated by means of micronucleus (MN) test and Total chromosomal aberration (TCA).

\section{Patients and Methods}

\section{Population of the study}

Fourty five males workers in chemical and pesticid shopes were included in the study, they were employed in three markets of chemicals and pesticides within Baghdad city, for the control group, a fifteen individuals were selected from the same age, sex and socio-economic status as that of the exposed group, these individuals didn't exposed to direct pesticides or chemicals and have no chemical theraby three months before sampling date. Information for personal, exposure and medical histories for each both control and exposed peoples was subjected on a questionnaire.

\section{Blood collection}

Blood samples were collected from volunteers by vein puncture in heparinized tubes. Samples were transported to the lab within one hour under sterilization and refrigeration for analysis of lymphocyte subsets and cytogenetic.

\section{Anslysis of lymphocytes subset}

Percentage of lymphocytes subset (\%CD3+), T helper lymphocytes (\%CD4+), $\mathrm{T}$ toxic lymphocytes (\% CD8+) and natural killer (NK) cells (\% CD16+-56+), were determined by flowcytometry as described in [10]. Multi-color immunophenotyping by Partec Cyflow Cube 6 flowcytometer and interpretation of markers by FACS Express 4 software was done at the private lab.

\section{Total chromosomal aberration (TCA) and}

\section{Micronuclei (MN)}

TCA and MN were investigated according to Verma and Babu, 1989 [11]. Whole blood was analyzed immediately by adding $0.5 \mathrm{~mL}$ of heparinized blood to $4.5 \mathrm{~mL}$ of RPMI 1640 medium provided by $10 \%$ of fetal bovine serum and $0.05 \mu \mathrm{g} / \mathrm{mL}$ of colchicine all tubes incubated at $37^{\circ} \mathrm{C}$ for $2 \mathrm{hrs}$. Then cells were exposed to hypotonic solution of $0.075 \mathrm{M} \mathrm{KCl}$ for $20 \mathrm{~min}$, after that fixative solution of 1:3 (glacial acidic acid and 
absolute methanol) was added by drop wise. Suspended cells were dropped on clean cold slides, and then air dried for 24 hrs. all dried slides y were stained with Giemsa stain for 2.5 mins. 250 well-spread metaphases per individuals have been tested under a light microscope (Olympus), to calculate both $\mathrm{MN}$ and TCA.

\section{Statistical analysis}

Data were analyzed using the statistical SPSS software version 16.0 was used to designate the significance between and within the groups by calculating analysis of variance ANOVAI and least significant differences assay (LSD) at level of significance $5 \%$, in addition to calculate $\mathrm{p}$ value and descriptive test to determine the significant for characteristics of the study population.

\section{Results}

The characteristics of the study population are summarized in Table (1). Both groups (exposed 45 and control 15) were identical in distribution of age and smoking habits, from observations there are no significant differences between two groups according to age $(31 \pm 15.12$ exp. and $29 \pm 11.45$ con.) respectively and smoking habits but there is statistical differences between smokers and thus persons with no smoking.

Table (1): Characteristics of the study population

\begin{tabular}{|l||c||c||c||}
\hline & Exposed (n=45) & Control (n=15) & P value \\
& & & \\
\hline \hline Age & $(14-55)$ & $(14-55)$ & 3.84 \\
& $8.5 \pm 6.8$ & $/$ & $/$ \\
\hline \hline Period of employment( years) & $8.9 \pm 2.3$ & $/$ & $/$ \\
\hline \hline Exposure time (hour/day) & & & \\
\hline \hline Smoking habits & $17(38 \%)$ & $4(27 \%)$ & $0.45^{*}$ \\
Non-smokers \\
smokers
\end{tabular}

\section{Biomarkers of genotoxicity}

From Table (2) the TCA was increased 1.6 fold in exposed group in smokers and nonsmokers people, while $\mathrm{MN}$ was increased 1.67 fold in exposed nonsmoker people and 1.59 in exposed smoker people with significant differences at $(\mathrm{p} \leq 0.05)$, while in Table (3) TCA increased 1.52 fold in smokers and 1.7 in nonsmokers the same increasing was recorded in $\mathrm{MN}$ to reach 1.43 fold in smokers and 1.44 fold in nonsmokers, both biomarkers (TCA and $\mathrm{MN}$ ) recorded significant differences at $(\mathrm{p} \leq 0.05)$. Further, a high correlation was recorded between frequencies of $\mathrm{MN}$ and TCA, smoking and frequencies of $\mathrm{MN}$ and TCA, when discussing the results important observation 
was appear, that smokers group effected by chemicals and pesticides but less than that in nonsmokers, Actually the effect was insignificant or impalpable but we can see a resistance from smoker group to chemicals and pesticides, this may be due to the continuous exposure to chemicals from cigarette causes innate resistance to other exposure.

Table (2): Results of cytotoxicity in chemicals exposed group

\begin{tabular}{|c|c|c|c|c|c|c|c|}
\hline & \multirow{2}{*}{$\begin{array}{l}\text { Number } \\
\text { of } \\
\text { examined } \\
\text { cell } \\
\end{array}$} & \multicolumn{2}{|c|}{ Control $(\mathrm{n}=15)$} & \multirow[t]{2}{*}{$\begin{array}{c}\text { Cells } \\
\text { Scored }\end{array}$} & \multicolumn{2}{|c|}{$\begin{array}{c}\text { chemical Exposed } \\
(\mathrm{n}=31)\end{array}$} & \multirow[t]{2}{*}{$\begin{array}{c}\text { Cells } \\
\text { Scored }\end{array}$} \\
\hline & & $\begin{array}{c}\text { Non } \\
\text { smokers }\end{array}$ & smokers & & $\begin{array}{c}\text { Non } \\
\text { smokers }\end{array}$ & smokers & \\
\hline $\mathrm{TCA} \pm \mathrm{SD}$ & 100 & $0.19 \pm 0.06$ & $0.23 \pm 0.02$ & 1500 & $0.29 \pm 0.19 *$ & $0.36 \pm 0.09^{*}$ & 3100 \\
\hline $\mathrm{MN} \pm \mathrm{SD}$ & 250 & $2.5 \pm 0.11$ & $3.1 \pm 0.21$ & 3750 & $3.7 \pm 0.31 *$ & $5.2 \pm 0.62 *$ & 7750 \\
\hline
\end{tabular}

Table (3): Results of cytotoxicity in pesticides exposed group

\begin{tabular}{|c|c|c|c|c|c|c|c|}
\hline & \multirow{2}{*}{$\begin{array}{l}\text { Number } \\
\text { of cell } \\
\text { examined }\end{array}$} & \multicolumn{2}{|c|}{$\begin{array}{l}\text { Control } \\
(\mathrm{n}=15)\end{array}$} & \multirow[t]{2}{*}{$\begin{array}{l}\text { Cells } \\
\text { Scored }\end{array}$} & \multicolumn{2}{|c|}{$\begin{array}{l}\text { Pesticides Exposed } \\
(\mathrm{n}=14)\end{array}$} & \multirow[t]{2}{*}{$\begin{array}{c}\text { Cells } \\
\text { Scored }\end{array}$} \\
\hline & & $\begin{array}{c}\text { Non } \\
\text { smokers }\end{array}$ & Smokers & & $\begin{array}{c}\text { Non } \\
\text { smokers }\end{array}$ & Smokers & \\
\hline TCA \pm SD & 100 & $0.19 \pm 0.06$ & $0.23 \pm 0.02$ & 1500 & $0.27 \pm 0.21 *$ & $0.44 \pm 0.1 *$ & 1400 \\
\hline $\mathrm{MN} \pm \mathrm{SD}$ & 250 & $2.5 \pm 0.11$ & $3.1 \pm 0.21$ & 3750 & $5.61 \pm 0.23 *$ & $7.11 \pm 0.51 *$ & 3500 \\
\hline
\end{tabular}
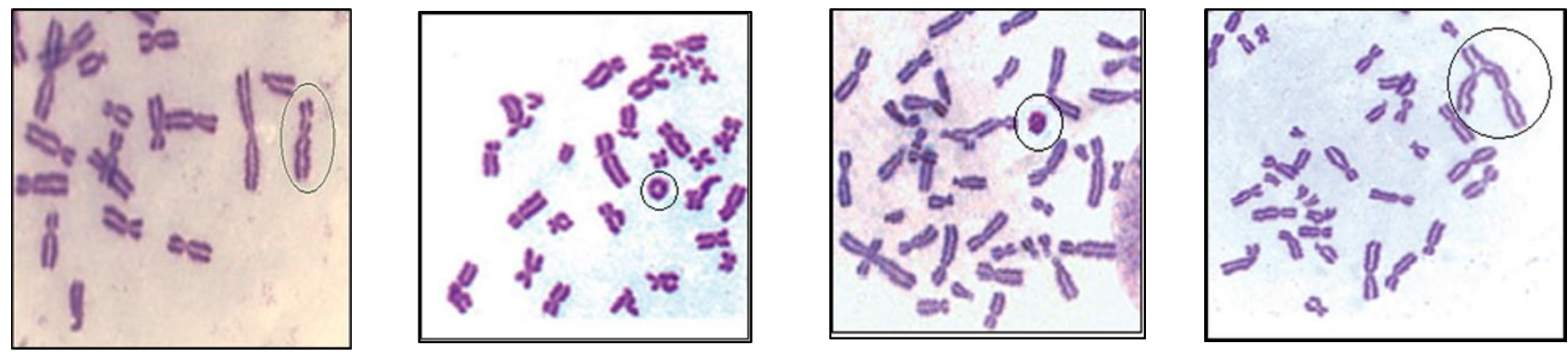

Chromaide exchange

Micronuclie

Ring chromosome

Chromatide break

Figure (1): Some chromosomal aberrations were investigated in chemical exposed people 
Lymphocytes subpopulation : Lymphocyte subpopulations analysis was summarized in Table (4) and Figue (2). Significant decreases were recorded in both $\mathrm{CD} 3+\%$ and $\mathrm{CD} 4+\%$ at $(\mathrm{P} \leq 0.05)$ while $\mathrm{CD} 8+\%$ and $\mathrm{NK}$ cells suffered significant increases in both exposed groups (chemical and pesticides) according to ANOVAI analysis. Lymphocyte subpopulations were determined as immunetoxicity markers in exposed people.

Table (4): Percentage of the lymphocytes subsets in the study groups

\begin{tabular}{|c|c|c|c|}
\hline$\#$ & $\begin{array}{c}\text { Control } \\
(\mathrm{n}=15)\end{array}$ & $\begin{array}{c}\text { Chemical } \\
\text { exposed } \\
(\mathrm{n}=31)\end{array}$ & $\begin{array}{c}\text { Pesticides } \\
\text { exposed } \\
(\mathrm{n}=14)\end{array}$ \\
\hline $\mathrm{CD} 3+\%$ & $63.12 \pm 1.02$ & $58.17 \pm 0.19^{*}$ & $51.22 \pm 0.2^{*}$ \\
\hline $\mathrm{CD} 4+\%$ & $33.23 \pm 0.92$ & $31.11 \pm 1.13^{*}$ & $31.41 \pm 2.33^{*}$ \\
\hline $\mathrm{CD} 8+\%$ & $18.12 \pm 1.13$ & $22.02 \pm 0.03^{*}$ & $21.06 \pm 0.13^{*}$ \\
\hline \hline $\mathrm{NK} \%$ & $11.12 \pm 0.11$ & $16.22 \pm 0.15^{*}$ & $19.34 \pm 0.34^{*}$ \\
\hline \hline $\mathrm{CD} 4+$ CD8+ ratio & 1.8 & 1.4 & 1.5 \\
\hline
\end{tabular}

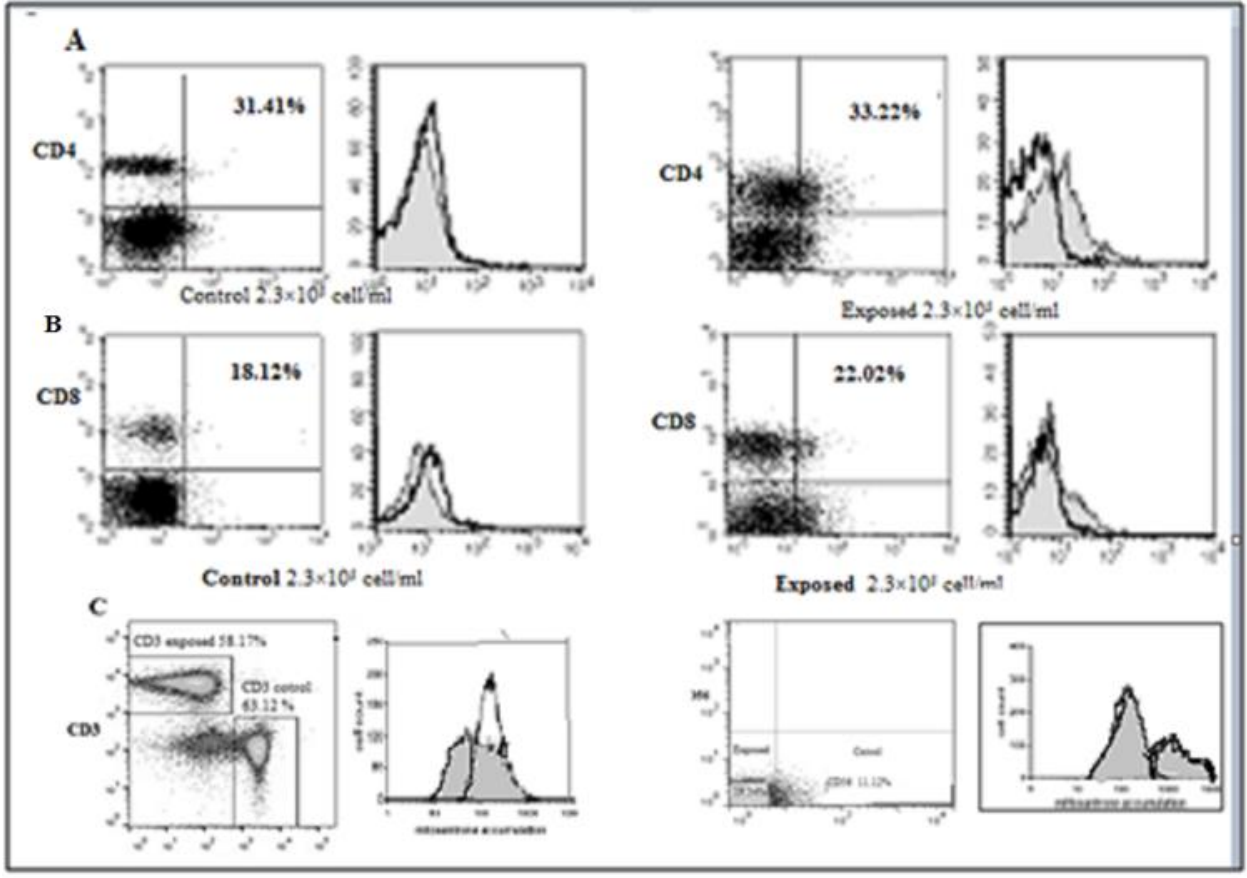

Figure (2): Flowcytometry analysis of (A) CD4 for exposed and unexposed people (B)) CD8 for exposed and unexposed people (C) ) CD3 for exposed and unexposed people and NK cell for exposed and unexposed people

\section{Discussion}

The main objective of this study was investigate the effects of exposure to complex mixture of chemicals and pesticides in workers within chemical and pesticides shops in three main markets in Baghdad city parallel to unexposed control group have the 
same individual characteristic. To evaluate the cytogenetic damage in peripheral blood lymphocytes was used, two types of parameters as a bio-monitoring parameters were determined $\mathrm{MN}$ and TCA.

Micronuclei (MN) and Total chromosomal aberrations (TCA) are good and potential parameters for monitoring of genotoxic effects in humans and many types of animals and plants [12] These two biomarkers may induce naturally or laboratory by chemical, physical and biological induced factors like arsenic, benzene, pesticides, radiation and microbial infections [13 and 14]. Micronuclei can be defined as fragments of chromosomes or the whole, therefore any clastogens and aneugens can cause this type of chromosomal abnormalities, MN assay are conducted in human peripheral blood lymphocytes is a prevalent genetic toxicology testing [15] The use MN has become standard assay for many epidemiological and exposed for many chemicals, toxicants, drugs and environmental pollutants [16 and 17], MN can measured in different types of cells such as buccal mucosa, urothelial cells and peripheral blood lymphocyte, the last one widely used in $\mathrm{MN}$ assay because life span of lymphocytes is longer than that of the other two exfoliated cell types, therefore, that

lymphocytes may yielded highest sum of MN count/1000 cells compared to other exfoliated cells [18 and 19]. From Table (2 and 3) and Figure (1) The increasing was clear in both parameters $\mathrm{MN}$ and TCA, in exposed group as a compare with control group.

Normal lymphocyte subset percentage ranges in healthy adult persons from $28 \%$ to $58 \%$ for CD4+ and $19 \%$ to $48 \%$ for CD8+ cells [20-22], from findings both type of cells within the normal range, but the percentage of CD4+ was decreases according to control associated with significant increases in CD8+ cells so the CD4+: $\mathrm{CD} 8+$ ratio was diminished to 1.4 and 1.5 chemical and pesticide exposed groups respectively, while control reported 1.8 , these reduction explain the amenability of such people to different and recurrent disease[23, 24]. From our observations through chemical markets tour, that ambient air of these shops saturated gases, vapors and different particulates (chemicals and dust), locally so rare specialized studies dealing with occupationally exposure to chemicals in such long hours of exposed $10 \mathrm{hrs} / \mathrm{day}$ and 60 hrs/ week this explain multiple changes in genetic material such as DNA reactivity, gene mutation, chromosomal breakage, aneuploidy, and oxidative stress, this certainly leads to different types of cancer especially leukemia, nasopharyngeal and sinonasal cancer. According to occupational safety and health standards (1910.1000 air contaminants) In case of a mixture of air contaminants an employer shall compute the equivalent exposure.

$\mathrm{Em}=(\mathrm{C} 1 \div \mathrm{L} 1+\mathrm{C} 2 \div \mathrm{L} 2)+\ldots(\mathrm{Cn} \div \mathrm{Ln})$

Where: Em is the equivalent exposure for the mixture. $\mathrm{C}$ is the concentration of a particular contaminant. $\mathrm{L}$ is the exposure 
limit for that substance specified in subpart $\mathrm{Z}$ of 29 CFR part 1910. The value of Em shall not exceed unity. So that exposure within the acceptable limits [25].

\section{Conclusions}

Actually, the findings of the present study compatible with many studies referred to immunotoxic and genotoxic effects of chemicals and/ or pesticides on populations environmentally and occupationally exposed to such contamination. Significant quantitative changes in both immunological and genetic status in exposed people was observed, thus more protective measures and other safety regulations should be emphasized for These workers, to prevent further exposure.

\section{References}

[1]Adamus T, Mikulenková I, Dobiáš L, Havránková J, Pek T. Cytogenetic methods and biomonitoring of occupational exposure to genotoxic factors . J. Appl. Biomed. 2006; 4: 197-203.

[2]Šmerhovský Z, Landa K, Rössner P. et al. Risk of cancer in an occupationally exposed cohort with increased level of chromosomal aberrations. Environ. Health Perspect. 2001; 109: 41-45.

[3]IARC: Monographs on the Evaluation of the Carcinogenic Risk of Chemicals to Humans. Vol. 34, IARC, Lyon, France 1984. [4]Prabha. Pooja C. Risk assessment of occupational exposure to pesticides among pesticide distributors of Punjab (India) using single cell gel electrophoresis. Int J Hum Genet. 2015;15(3): 149-155.
[5]Tsimbiri P, Moturi N, Sawe J, Henley P, Bend R. Health impact of pesticides on residents and horticultural workers in the Lake Naivasha Region, Kenya. ODEM, 2015; 3: 24-34.

[6]Dubravka J ,Jelena P , Boban R , Ljiljana R , Milos P, Vaskrsije J , Aleksandar M" Cytogenetic biomontring in a Serbian population occupational exposed to a complex mixture of pesticides. Gentika.2013; 45: (1) 121-133.

[7]Coelho P, Costa S, Costa C, Silva S, Walter A,Ranville J, Pastorinho M, Harrington Taylor C, Dall'Armi V, Zoffoli C, Candeias E, Silva F, Bonassi S, Laffon B, Teixeira $\mathbf{J}$ Immunological alterations in individuals exposed to metal (loid)s in the Panasqueira mining area, Central Portugal. Science of the Total Environment.2014, 475: $1-7$.

[8]Costa C, Costa S, Silva S, Coelho P, Botelho M, Gaspar J, Rueff J, Laffon B, Teixeira1 J. DNA damage and susceptibility assessment in industrial workers exposed to styrene. Journal of Toxicology and Environmental Health, Part A, 2012. 75:735746.

[9]Schins RP. Mechanisms of genotoxicity of particles and fibers. Inhal Toxicol .2002; 15 : 213-20.

[10]Lestón GJ, Torres RJ, Vilares M, Pinto R, Cunha L, Prista J. Biomonitoring of a population of Portuguese workers exposed to lead. Mutat Res. 2011; 721:81-8.

[11]Verma R, Babu A.Human chromosomes: Mannual of Basic techniques. Pregramon press, New York. 1989. 
[12]Guzman P, Sotelo-Regil RC, Mohar A, Gonsebatt ME. Positive correlation between the frequency of micronucleated cells and dysplasia in papanicolaou smears. Environ Mol Mutagen 2003, 41(5):339-343.

[13]Dantas J, Cézar A, Pombo-de-Oliveira MB, man SK. In Utero Pesticide Exposure and Leukemia in Brazilian Children $<2$ Years of Age. Environmental Health Perspectives .2012; 269-275.

[14]Gulnara SA. HLA Typing and Chromosomal Aberrations Caused by Chemical Agents. International Journal of BioMedicine. 2014; 4(4) S20-S22.

[15]Teixeira JP, Laffon B. Occupational and environmental health issues in Portugal. Journal of Toxicology and Environmental Health, Part A, 2012; 75:721, 2012.

[16]Holeckova B, Sivikova PK, DianovskyJ. Chromosomal aberrations in humans induced by benzene. Ann Agric Environ Med. 2004; 11: 175-179.

[17]Carere A, Andreoli C, Galati R, Leopardi P, Marcon F, Rosati MV, et al. Biomonitoring of exposure to urban air pollutants: analysis of sister chromatid exchanges and DNA lesions in peripheral lymphocytes of traffic policemen. Mutat Res. 2002; 518: 215-24.

[18]Bolognesi C, Gallerani E, Bonatti S, De Ferrari M, Fontana V, Valerio F, et al. Sister chromatid exchange induction in peripheral blood lymphocytes of traffic police workers. Mutat Res. 1997; 394: 37-44.

[19]Bonassi S, Znaor A, Ceppi M, Lando C, Chang WP, Holland N, et al. An increased micronucleus frequency in peripheral blood lymphocytes predicts the risk of cancer in humans. Carcinogenesis. 2007; 28: 625-31. [20]Gandhi G, Naru J, Kaur M, Kaur G. DNA and Chromosomal Damage in Residents Near a Mobile Phone Base Station. Int J Hum Genet. 2104; 14(3,4): 107-118. [21]Zhang L, Venkatesh P, Creek ML, Smith MT. Detection of 1,2,4- benzenetriol induced aneuploidy and microtubule disruption by fluorescence in situ hybridization and immunocytochemistry. Mutat Res.1994, 320, 315-327.

[22]Reichert T,DeBruyere M, Deneys V, Totterman T, Lydyard P, Yuksel F, et al. Lymphocyte subset reference ranges in adult Caucasians. Clin Immunol Immunopathol. 1991; 60:190-208.

[23]Bofill M,Janossy G, Lee CA, MacDonald-Burns D, Phillips AN, Sabin C, et al. Laboratory control values for CD4 and CD8 T lymphocytes. Implications for HIV-1 diagnosis. Clin Exp Immunol. 1992; 88:243252.

[24]Uppal S, Verma S, Dhot BS. Normal Values of CD4 and CD8 Lymphocyte Subsets in Healthy Indian Adults and the Effects of Sex, Age, Ethnicity, and Smoking. Cytometry Part B (Clinical Cytometry) .2003; 52 B: 32-36.

[25]Occupational Safety \& Health Administration. Subpart $\mathrm{Z}-$ toxic and hazardous substances 1910.1000-air contaminants.

https://www.osha.gov/pls/oshaweb/owadisp.s how_document?p_table $=$ federal_register\&p_ $\mathrm{id}=13306$. 